\title{
Retrospective Analysis of Financial Research Among Korean Institutions and Authors (1990-2010)*
}

\author{
Kam C. Chan** \\ Department of Finance, Western Kentucky University \\ Chih-Hsiang Chang \\ Department of Finance, National University of Kaohsiung \\ Yining Chen \\ Department of Accounting, Western Kentucky University
}

Received 10 April 2011; Accepted 1 June 2011

\begin{abstract}
Using published studies in 24 leading finance journals across 21 years (1990-2010), we investigate the financial research productivity among Korean academic institutions and scholars. Overall, 61 Korean universities contribute a total of 158.50 weighted articles and make 382 appearances during the full sample period. The five most productive Korean universities are Korea Advanced Institute of Science and Technology, Korea University, Seoul National University, Yonsei University (Seoul), and SungKyunKwan University. Although the financial research productivity among Korean universities fluctuates yearly, there has been an increasing trend since 1990 and a significant escalation in the most recent 5 years. We also notice that the Korean authors who are successful in international finance journal publications have had prior international experience through affiliations with international institutions during their studies or academic career.
\end{abstract}

Keywords Financial research; Journal publications; Research productivity; Korean JEL Classification: G0

\footnotetext{
*Acknowledgments: We acknowledge the helpful comments from two anonymous reviewers, an associate editor, and the Editor (Kee Chung) and the programming assistance from Christine Lai.

${ }^{* *}$ Corresponding author: Kam C. Chan, Department of Finance, Western Kentucky University, Bowling Green, KY 42101, USA. Tel: +1 (270)745-2977, Fax: +1 (270)745-5284, email: johnny.chan@wku.edu.
} 


\section{Introduction}

Korean higher education has undergone rapid expansion over the past several decades (Kim and Lee, 2006). With major efforts, including reform initiated by government (i.e. Brain Korea 21) and investment supplied by private sectors, Korean universities have transformed into world-class higher education institutions. One of the common objectives has been to foster world-class research infrastructure and to advance research productivity. As a result of the continuous efforts, the number of articles by Korean scholars published in international journals has increased considerably along with other advancements in intellectual contributions (Moon and Kim, 2001). While several recent studies consider the financial research productivity in the Asia-Pacific region (e.g. Chan et al., 2001, 2005, 2011c; Jarnecic et al., 2008), few studies examine the financial research contributions by Korean academic institutions and Korean authors.

The objective of this paper is to present a retrospective analysis of financial research among Korean academic institutions and authors. Based on the publication records among a set of 24 leading and high quality finance journals during 19902010, we provide several interesting findings. First, 61 Korean universities published a total of 158.50 weighted articles and 382 appearances during the full sample period. In the most recent 5 years (2006-2010), Korean universities have undergone significant progress, as evidenced by an elevated research output. The share of output during 2006-2010 to the full sample period is $47.8 \%$. Second, although the financial research output among Korean universities fluctuates yearly, there has been an increasing trend since 1990 and a significant escalation in the most recent 5 years. Third, among the leading contributing authors who are affiliated with Korean academic institutions, the majority have prior international experience. Finally, with regard to financial research productivity, Korean authors are comparable to authors in the Asia-Pacific region and leading Korean universities are comparable to their counterparts in other Asia-Pacific countries.

\section{Literature Review}

Most countries recognize the importance of investing in their higher education to advance economic growth. Higher education institutions compete among themselves to secure government research funding and to attract first-class faculty and students. $\mathrm{Hu}$ and Gill (2000) suggest that being classified as a "research university" is clearly an indicator for quality programs. Chan et al. (2011c) argue that the findings of research productivity analysis can help governments and other constituents to assess the performance of academic institutions, with implications for faculty promotion, tenure, merit, enrollment, employment, and resource allocation decisions.

Prior research assessment studies among the business disciplines can be clustered into three groups. The first group of studies assesses research productivity in a global context. For example, Chan et al. (2003) examine 12 years (1990-2001) of research records from a set of 16 leading finance journals and provide a global ranking of 
academic institutions. Chan et al. (2007) expand the global ranking study of academic institutions by Chan et al. (2003) to a longer time period (1990-2004) and to 21 finance journals. To determine which authors are most prolific and to help schools form realistic expectations about scholarly work, Heck and Cooley (2009) provide an exceedingly long-term (1959-2008) study of finance research productivity.

The second group of the research assessment studies focuses on the regional performance of institutions and authors. These regional-focused studies aim to provide an assessment of the research productivity of the institutions in their respective regions. Among these studies are Chan et al. (2001, 2005), Jarnecic et al. (2008), and Chan et al. (2011c) focusing on Asian finance; Kalaitzidakis et al. (1999) on European economics; Chan et al. (2004, 2011a) on European finance; and Carmona et al. (1999) and Chan et al. (2006) on European accounting. Apart from gauging performance in a regional setting, these studies help to motivate scholars and institutions in their research efforts.

The third group of the literature examines the research productivity in an individual country setting. The primary purpose of these country-specific studies is to report the research effectiveness of a specific discipline in a particular country. For example, Ashton et al. (2009) use the 2001-2007 data submitted to the UK's Research and Assessment Exercise in 2008 to gauge the general performance of UK accounting and finance departments. Pomfret and Wang (2003) examine the research progress of Australian academic economists and economics departments. Anderson and Tressler (2008) examine the research output of economics departments in New Zealand. Among those who take interest in Canada, Booth and Heath (1990) pioneer an early study on the research productivity of assorted Canadian finance departments in 1988 and 1989. Chan et al. (2011b) study the research productivity among Canadian finance departments over a longer time period (1990-2008). Lucas (1995) and Davies et al. (2008) analyze the economics research in detail. Rugman (2008) presents a thorough qualitative discussion on the development of international business research in Canada since the 1970s. Moreover, Serenko et al. (2008) examine the citations of information system research articles collected in the Proceedings of Administrative Sciences Association of Canadian Conference.

Although there are published studies that assess the research productivity of business disciplines in global, regional, and national settings, there are no studies that examine research productivity in the business disciplines among Korean institutions and scholars. It is our intention to commence a study to investigate Korean universities and scholars in terms of their effectiveness in publishing financial research over a long-term period.

\section{Data and Method}

Following Chan et al. (2011c), we include their 23 finance journals in our study. In light of its regional focus and popularity among Asian authors, we also add the International Review of Economics and Finance. Appendix 1 presents a list of the 
final 24 journals. ${ }^{1}$ We have collected authors' institutional information from each article. In the cases where information is not apparent, we have verified author details by examining respective websites, library searchable databases, and Google Scholar. Over the study period (1990-2010), these 24 journals published a total of 19501 articles. We do not include comments, replies, errata, editorials, editors' introductions, or book reviews.

We use the weighted number of articles (hereafter wt-articles) as the primary metric. The weights are the number of authors and co-affiliations. For instance, an article has A and B as coauthors, with A affiliated with Institution X and B affiliated with Institutions $\mathrm{Y}$ and $\mathrm{Z}$. Using the weighting scheme, Institution $\mathrm{X}$ would receive 0.5 credits and Institutions $Y$ and $Z$ would each receive 0.25 credits for the article.

Chan et al. (2011c) suggest that there are differences in quality among the 24 finance journals. We offer two alternative metrics. First, we use the author-affiliation index (AAI) to weigh each article. The AAI values are adopted from Chen and Huang (2007). The index value reflects the percentage of authors from a predetermined number of "top-ranked" institutions that appear in each journal. In general, the journals that have a large percentage of authors from top-ranked institutions would have a high AAI score. AAI values of all journals are disclosed in Appendix $1 .^{2}$ Second, we use the wt-articles in a smaller set of seven premier finance journals (Journal of Finance, Journal of Financial Economics, Review of Financial Studies, Journal of Financial and Quantitative Analysis, Journal of Business, Financial Management, and Journal of Banking and Finance) to provide the other alternative metric. We also use the total appearances of each institution to compliment the performance measures. Nonetheless, we primarily use wt-articles to provide the in-depth analyses.

With respect to authors, we do not distinguish Korean and non-Korean authors if they are affiliated with a Korean academic institution. ${ }^{3}$ For international and nonacademic institutions, we use a computer program to identify authors with common Korean last names and first names. In addition, we also use the Korean Finance Association website to identify Korean scholars who are working for international institutions. ${ }^{4}$

Several caveats are attached to our research method and findings. First, we do not include authors' pre-1990 publications. Second, by confining our study to 24 finance journals, we undoubtedly exclude authors' research output in high quality journals in other disciplines. Third, we consider the quantity of leading and high quality journal publications without incorporating the impact of the authors' specific research articles.

\footnotetext{
${ }^{1}$ We do not include Asia-Pacific Journal of Financial Studies due to its short history of being affiliated with a major publisher and because the authors of its articles are overwhelmingly from Korean institutions.

${ }^{2}$ Chen and Huang (2007) do not provide an AAI value for Accounting and Finance.

${ }^{3}$ There were only two non-Korean authors affiliated with Korean institutions in our sample.

${ }^{4}$ http://www.k-afa.org/docs/members.php?dataSubmitted=life (accessed 18 March 2011).
} 


\section{Results}

\subsection{Productivity of Korean Institutions}

Using the wt-articles, the AAI-articles, as well as total appearance in 24 finance journals, we provide a meticulous examination of the research performance of Korean universities. Based on the results presented in Table 1, a total of 61 Korean academic institutions have at least one appearance. These 61 institutions contribute a total of $158.50 \mathrm{wt}$-articles and 4504.27 AAI-articles, with 382 total appearances during the full sample period.

Based on the wt-articles (column 3 of Table 1), the top five most productive Korean universities are the Korea Advanced Institute of Science and Technology (KAIST), Korea University, Seoul National University, Yonsei University (Seoul), and SungKyunKwan University. Using total appearance (column 6 of Table 1) for ranking, the top five universities remain the same. When we use AAI-wt articles, Korea University is ranked first above KAIST. Worth mentioning is that many of the 61 Korean universities had 10 or fewer total appearances in the 24 publication. Financial research studies over the past 21 years have been heavily clustered among a few highly ranked Korean institutions.

To validate the results attained, we look into the productivity of Korean institutions publishing in seven premier finance journals. The seven journals are the topseven journals specified by Heck and Cooley (2009), except for the Journal of Money, Credit and Banking which is replaced by the Journal of Business. The ranking of Korean institutions, by the wt-articles, the AAI-articles, and total appearance in the top-seven finance journals, is reported in Appendix 2. Noteworthy is that the five Korean institutions that publish the most in the top-seven finance journals are Korea University, Seoul National University, KAIST, SungKyunKwan University, and Hanyang University (Seoul). It is almost the same list as in Table 1 with the exception that Hanyang University (Seoul) replaces Yonsei University (Seoul) as the fifth-ranked institution.

Panel A of Table 2 reports the published studies of Korean academic institutions by respective journals. According to the total wt-articles, the finance journals that Korean institutions published in most frequently are the Journal of Future Markets (17.75), the Pacific-Basin Finance Journal (16.67), the Journal of Business Finance and Accounting (16.17), the Journal of Banking and Finance (14.56), and the Review of Quantitative Finance and Accounting (13.58).

\subsection{Productivity of Korean Institutions: Trend over Time}

Our database offers us an opportunity to examine the change in research output over different periods. In particular, to examine the recent development of financial research in Korean institutions, we partition the database and calculate the proportion of articles published over the past 5 years (2006-2010) and the past 10 years (2001-2010). The percentage of wt-articles published in the most recent 5 and 10 years are shown in columns (9) and (11) of Table 1. Overall, the research output 


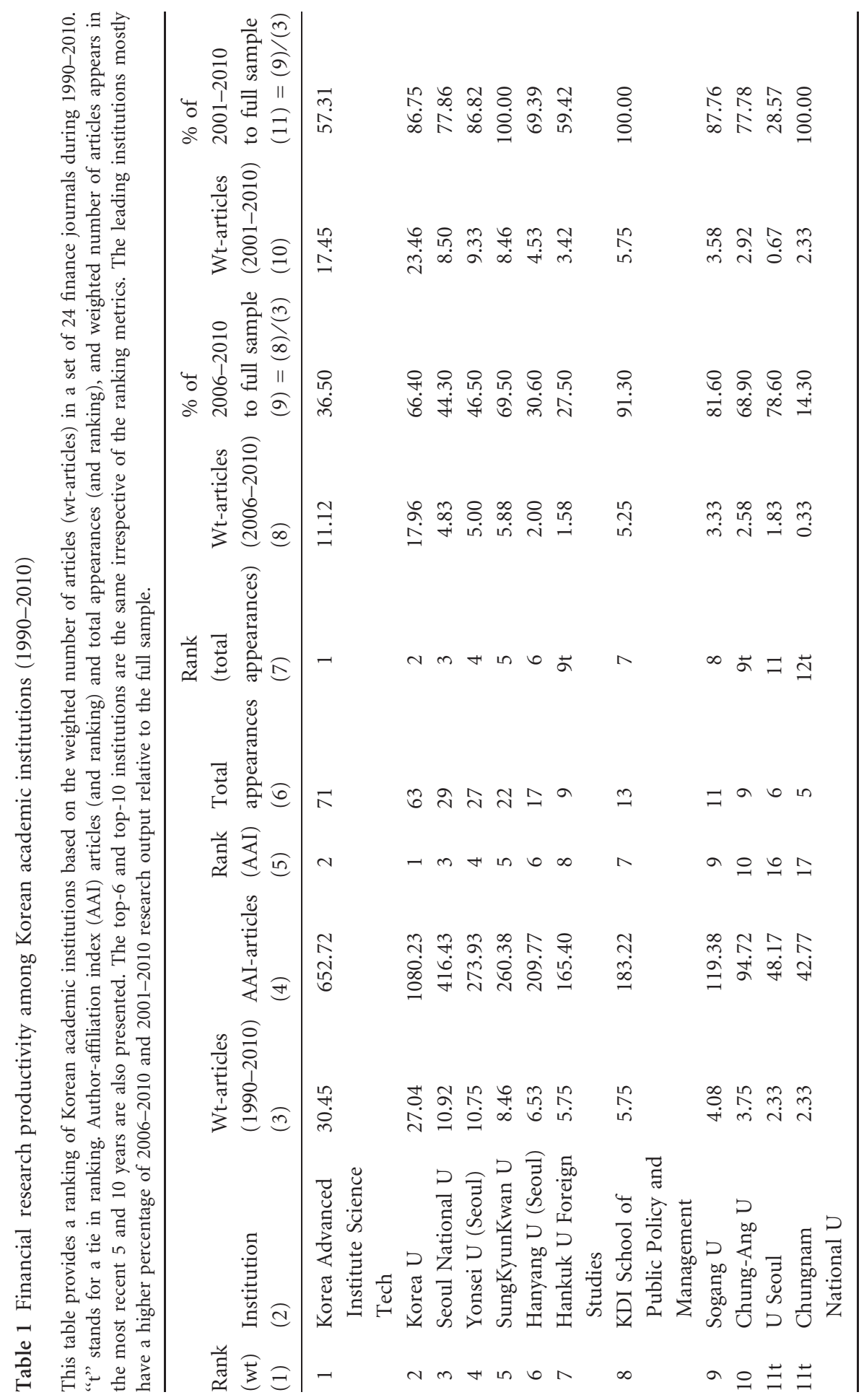


A Retrospective Analysis of Financial Research Among Korean Institutions and Authors

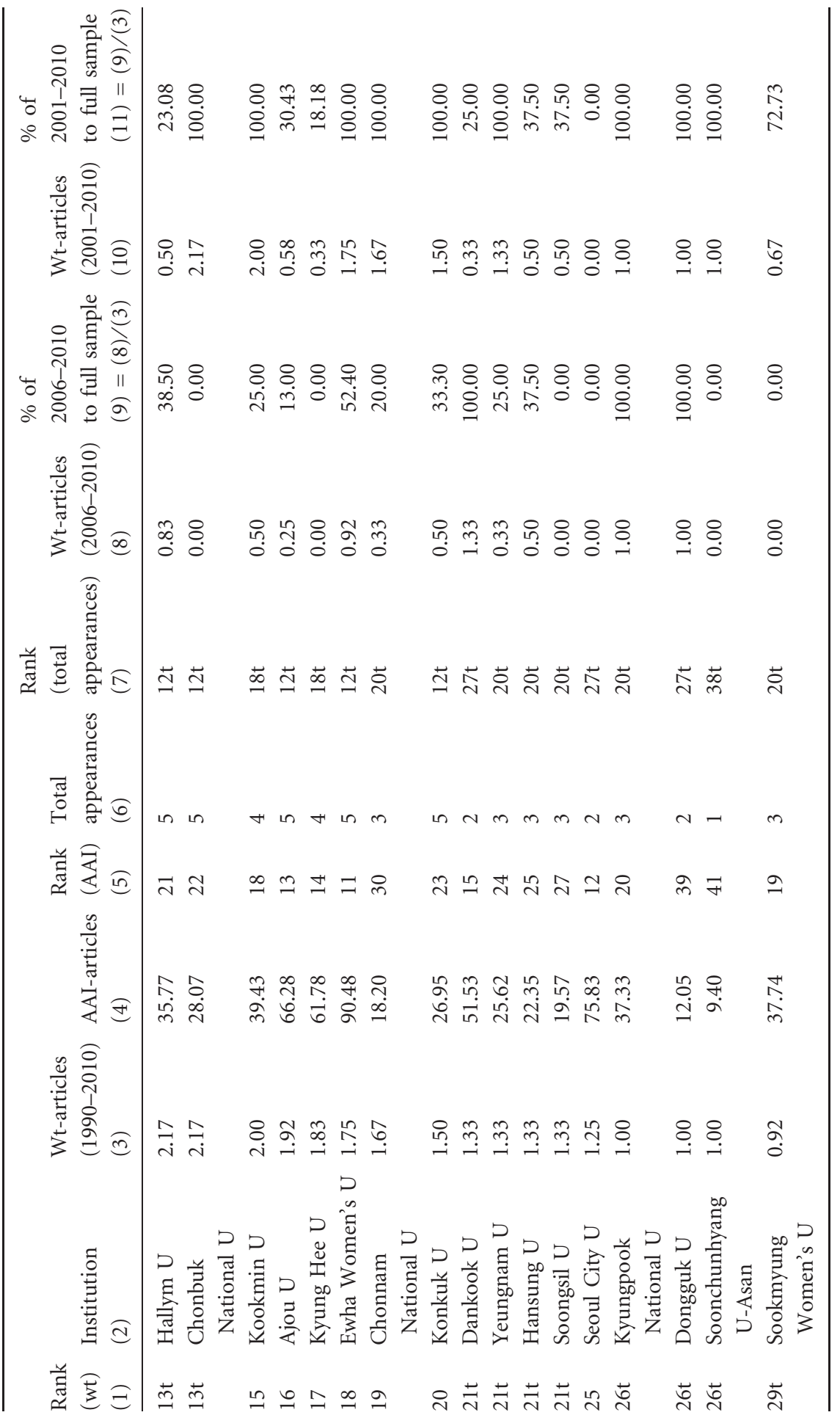




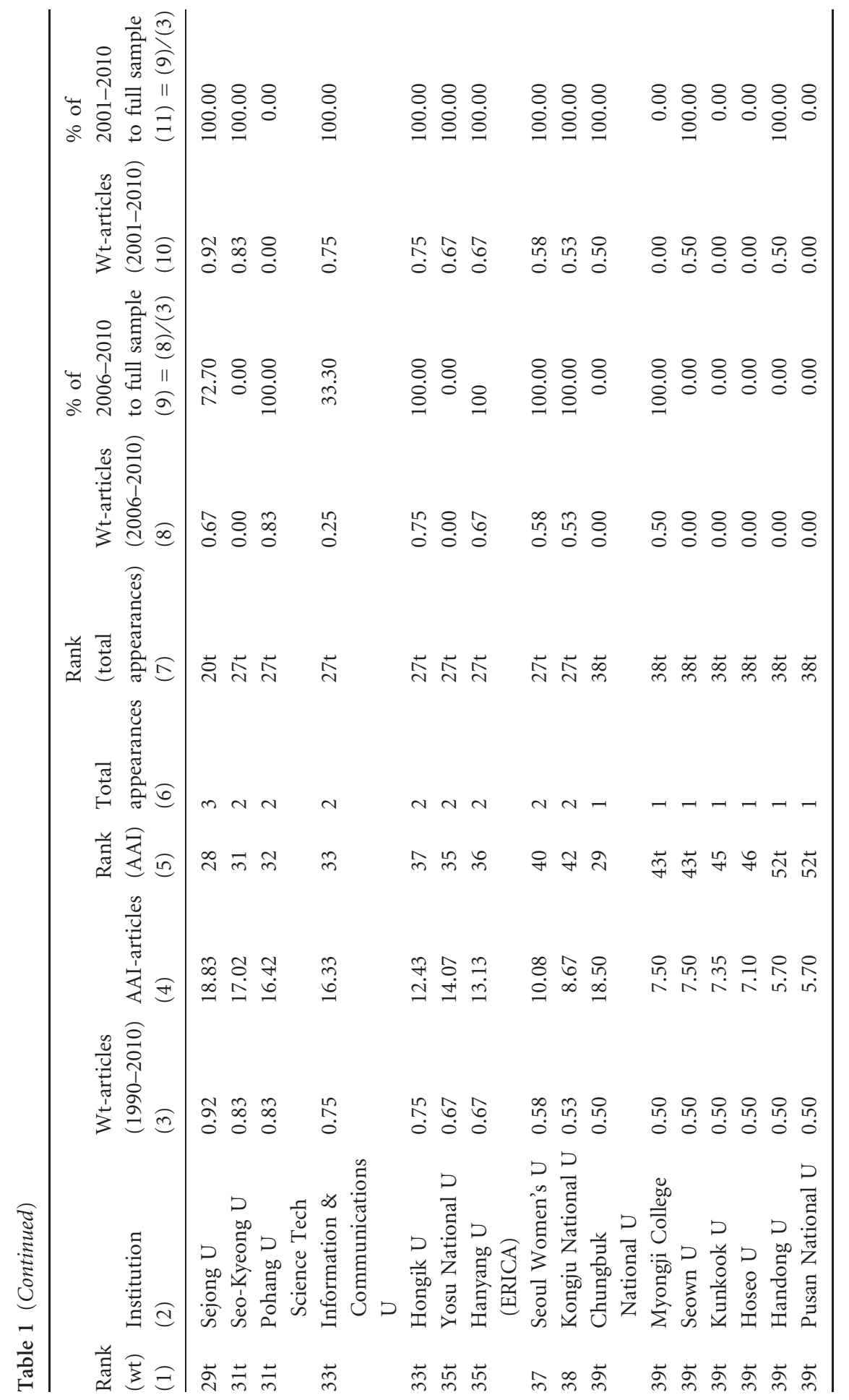


A Retrospective Analysis of Financial Research Among Korean Institutions and Authors

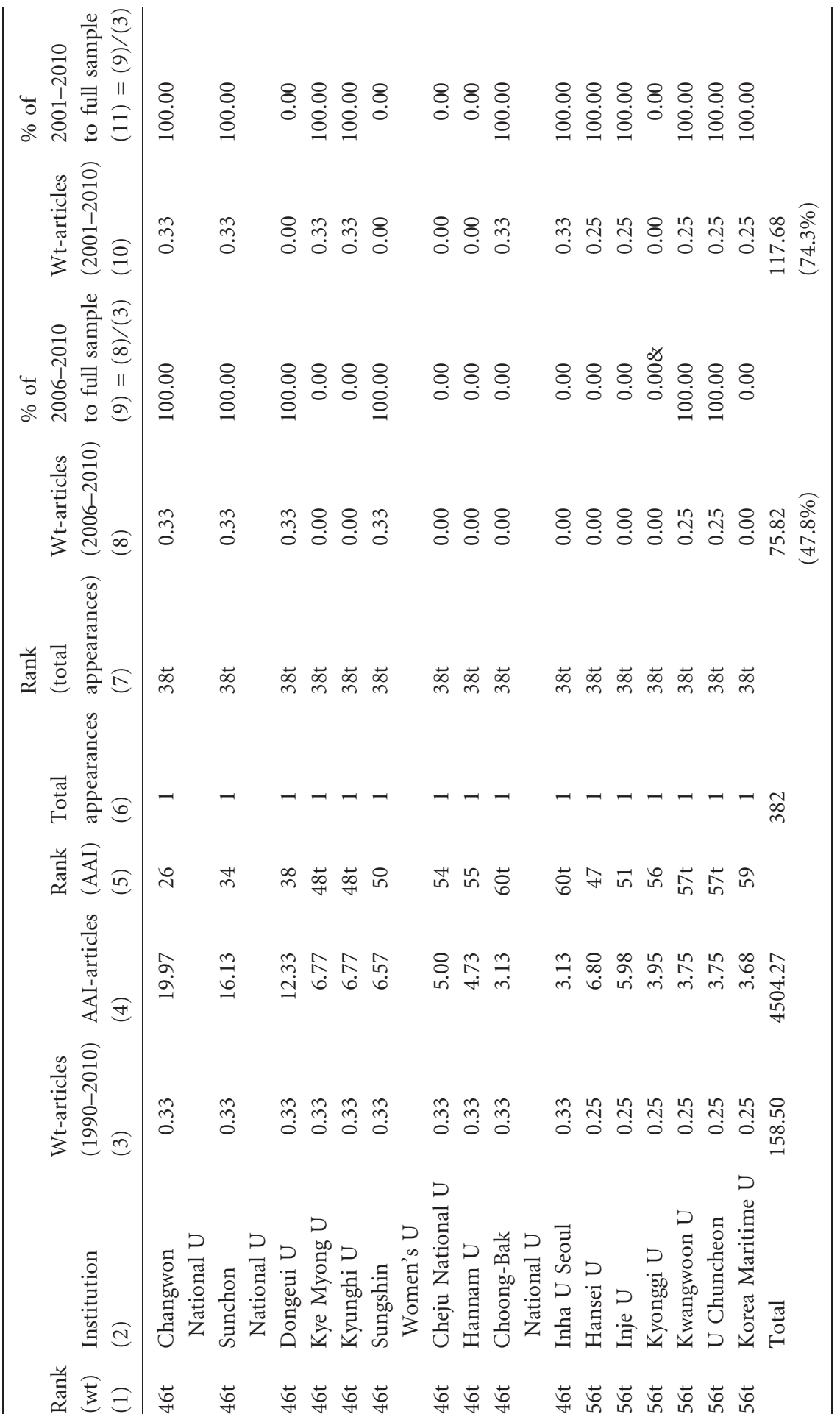




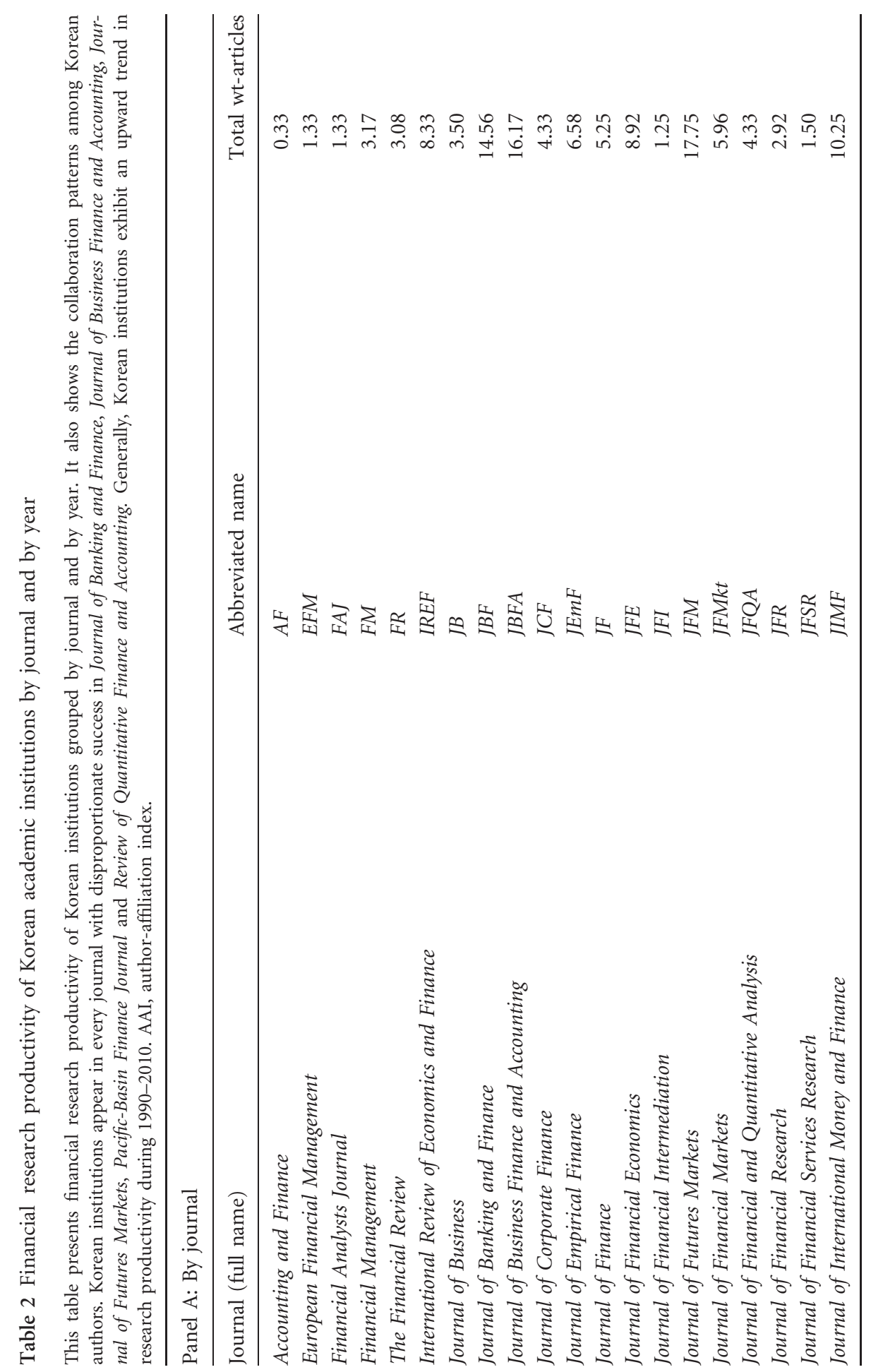


A Retrospective Analysis of Financial Research Among Korean Institutions and Authors
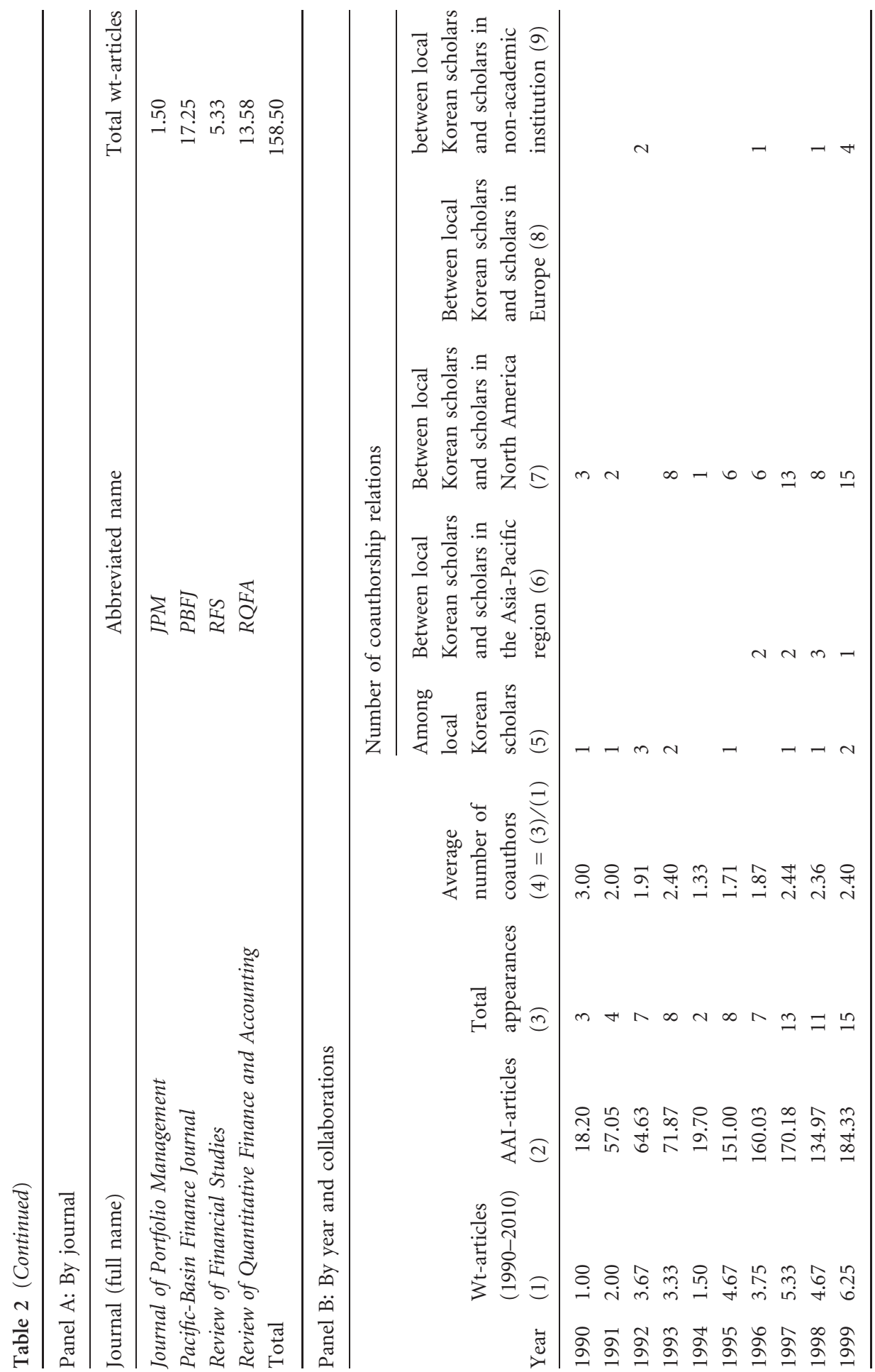


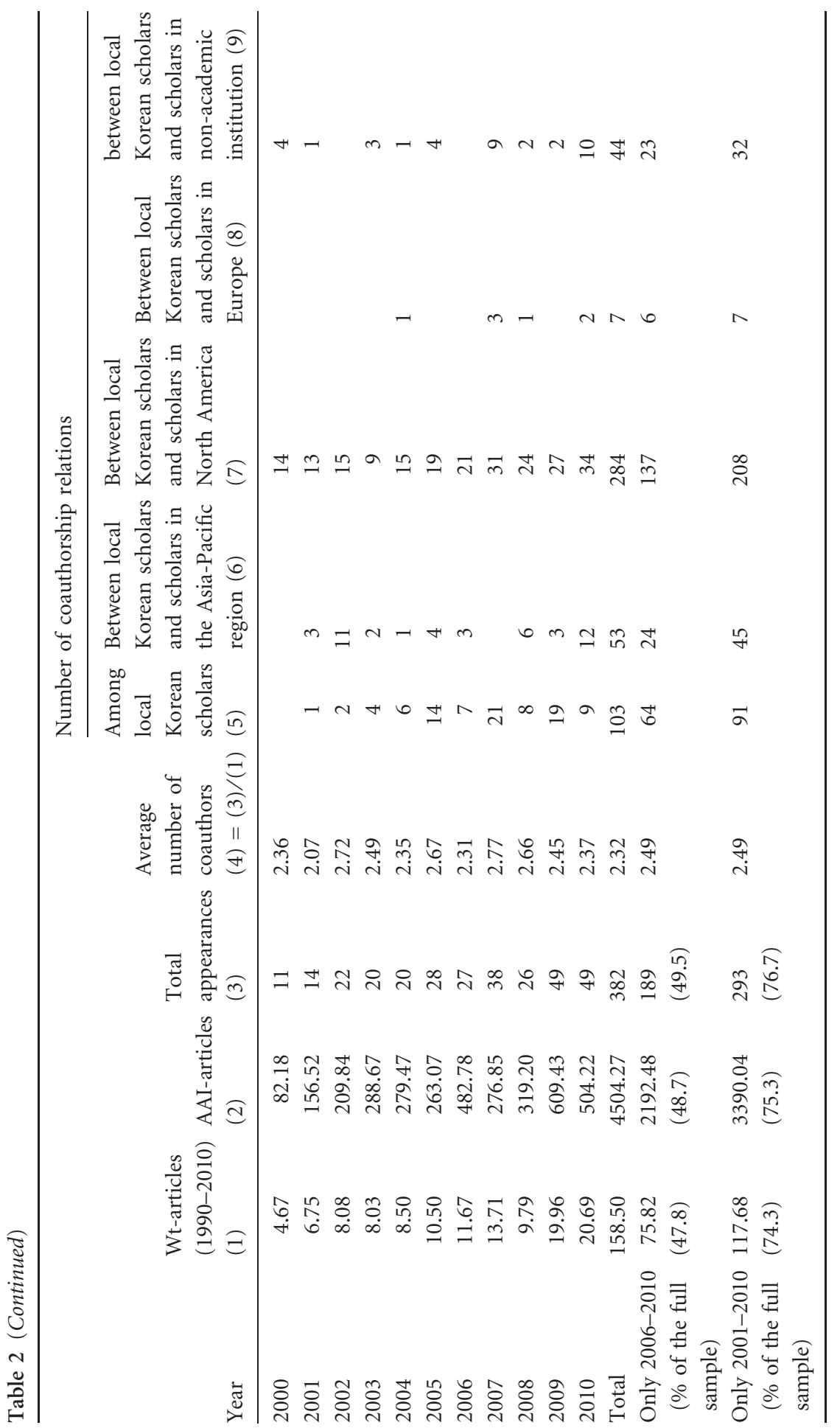


over 2006-2010 and 2001-2010 make up 47.8 and 74.3\% of the full sample. Over the past 5 years, while all top-10 universities have had greater than $23.8 \%$ (5 out of 21 years) of the weighted number of articles published in the past 5 years of the publication period, the KDI School of Public Policy and Management, Sogang University, SungKyunKwan University, Chung-Ang University, and Korea University reveal the most sizable upsurges. If we examine only the past 10 years, many universities have all of their wt-articles published. Therefore, the results in Table 1 suggest that the progress of financial research among Korean universities began to take shape over the past 10 years, with noticeable advances in the most recent 5 years.

Panel B of Table 2 provides a trend analysis of the research output. Across the 21-year study period, the financial research productivity of Korean institutions steadily improves from a total appearance of two articles in 1990 to 49 articles in 2010. Equivalent evidence can be observed from the wt-articles and the AAI-articles. In fact, nearly half of the articles across the 21-year study period were published in the past 5 years (2006-2010). In the most recent 2 years (2009 and 2010), Korean universities have been notably productive, with 48 and 49 total appearances and approximately 20 wt-articles published each year. We plot the financial research productivity of Korean institutions across years in Figure 1. The graph depicts the trend evidenced by the wt-articles, the AAI-articles, and total appearance. All three metrics reveal a clear increasing trend.

\subsection{Research Collaborations}

Our long-term analysis allows us to shed light on the perspectives of research collaborations among scholars in Korean institutions. We calculate a ratio of total appearance to wt-articles over time in Table 2 column (4) to show the average number of coauthors for articles produced by Korean institutions. ${ }^{5}$ The average number of coauthors is 2.49 for the past 5 and 10 years, which is slightly higher than the full sample of 2.32. We also decompose the coauthorship relation into among local scholars in Korea, between local Korean and Asia-Pacific scholars, between local Korean and European scholars, between local and North America scholars, and between local Korean and non-academic scholars. ${ }^{6}$ The results are in the last five columns of Panel B of Table 2. There are several interesting findings. First, the collaborations are primarily driven by Korean and North America scholars. Second, the collaboration among local Korean scholars has been on the

\footnotetext{
${ }^{5}$ For example, if the wt-article statistic is the same as the total appearance statistics, then the value of the ratio is one, which suggests that all articles are solo-authored. Similarly, when the wt-article statistic is only $50 \%$ of the total appearance statistics, the ratio has a value of 2 , indicating that each article, on average, has two coauthors.

${ }^{6}$ For a two-author article (by A and B), there is only one coauthorship relation. For a threeauthor article (by $\mathrm{A}, \mathrm{B}$, and $\mathrm{C}$ ), we have three coauthorship relations ( $\&$ \& $\mathrm{B}, \mathrm{A} \& \mathrm{C}$, and $\mathrm{B}$ \& C). With a four-author article (by A, B, C, and D), we would have six coauthorship relations (A \& B, A \& C, A \& D, B \& C, B \& D, and C \& D).
} 
Figure 1 Finance research productivity by year among Korean institutions.

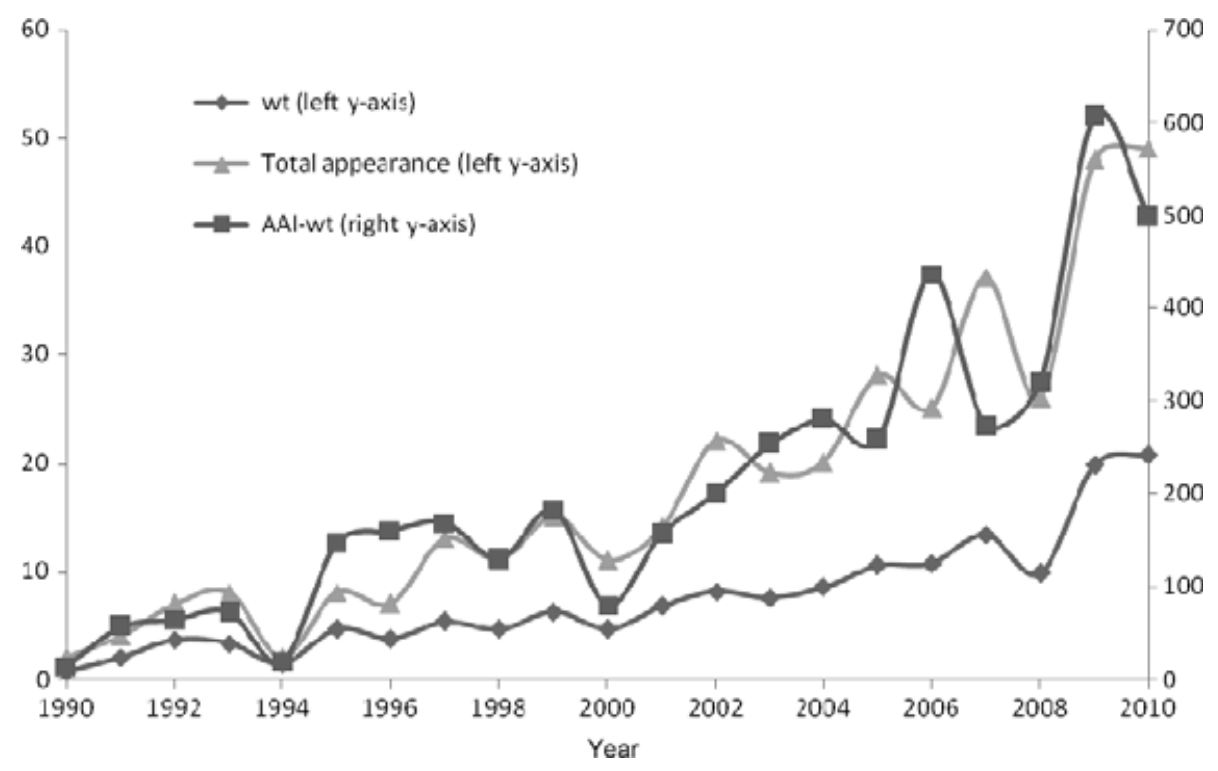

This figure presents the wt-articles and total appearances (on the left axis) and AAI, author-affiliation index (AAI) articles (on the right axis) among authors who are affiliated with Korean academic institutions. All three measures exhibit a visible upward trend during 1990-2010.

rise in the most recent five years. Third, collaboration between local Korean and European scholars is scarce. Figure 2 plots average number of coauthors, collaboration among local Korean sscholars, between local Korean and other Asia-Pacific Scholars, and between local Korean and North America scholars. With the exception of the collaborations between local Korean and Asia-Pacific scholars, all exhibit upward trends.

\subsection{Productivity of Korean Scholars}

In almost all countries, a strong record of successful research is essential for faculty advancement. Korean financial scholars affiliated with Korean and international institutions have been successful in publishing in international finance journals. Based on the wt-articles contributed to the 24 finance journals over the study period, Table 3 lists the top 20 researchers $^{7}$ affiliated with Korean institutions (Panel A), the top 20 Korean researchers affiliated with international and non-academic institutions (Panel B), and a comparison of the groups during 1990-2010, 2001-2010, and 2006-2010. Wt-articles, AAI-articles, and total appearances are also included in the table. In Panel $\mathrm{A}$, the 20 leading researchers affiliated with Korean institutions represent 9 of the 61 (15\%) Korean institutions;

\footnotetext{
${ }^{7}$ Because of ties, we may have more than 20 scholars in some panels in Table 3.
} 
Figure 2 Finance research productivity by year among Korean institutions.

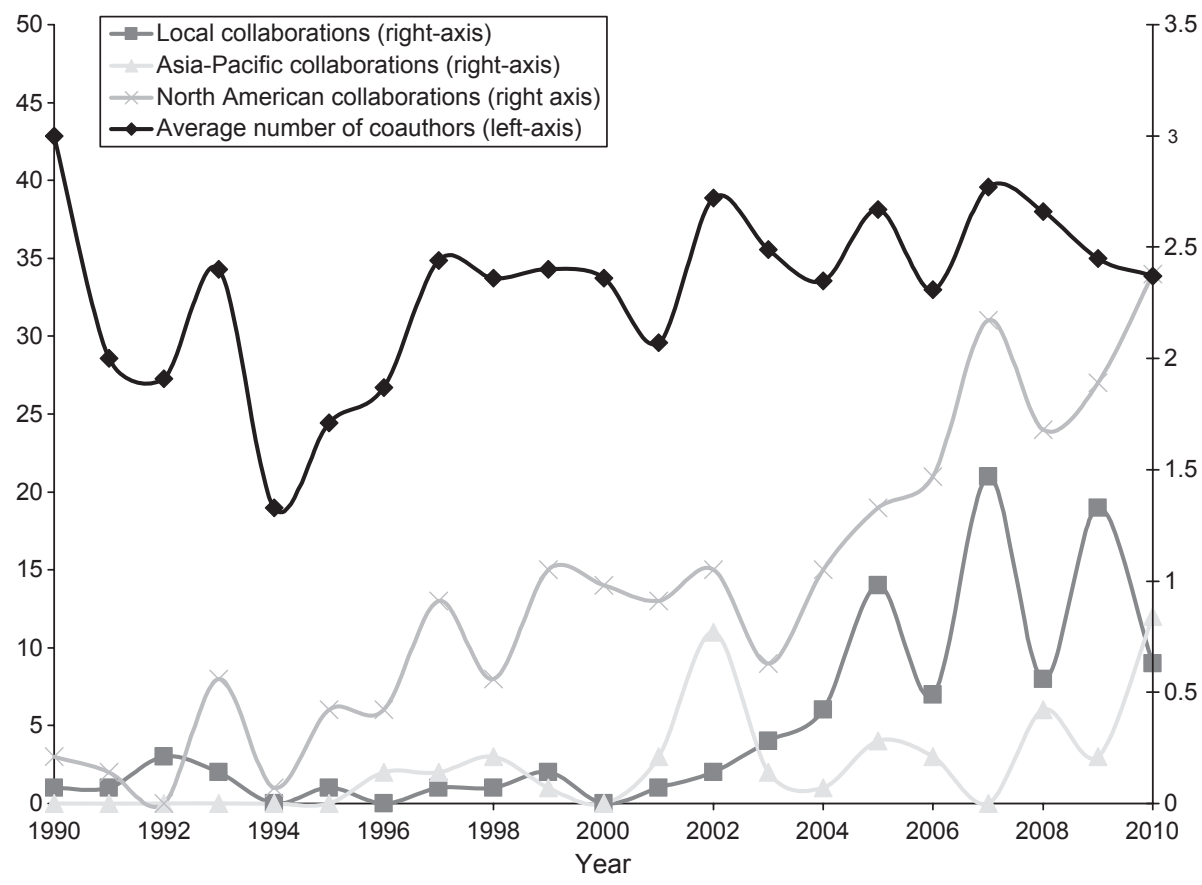

This figure shows the average number of coauthors in the left axis and the total number of coauthorship relations among local Korean scholars, between local and Asia-Pacific scholars, and between local and North America scholars.

and they contribute 77.74 wt-articles and 2645.31 AAI-articles, and have 156 total appearances. Among the 20 most productive researchers, five are from SungKyunKwan University, four are affiliated with Seoul National University, and three are with Korea University and Yonsei University (Seoul). With the exception of three, all had prior international experience. The above results suggest that a large proportion of financial research is contributed by a selected group of faculty with international experience who are affiliated with higher-ranked Korean universities. The high concentration of research productivity among only a small group of scholars might not be good news for Korean policy-makers as the Korean government would probably like to see the increase in research productivity more evenly spread out.

Other than the researchers who are affiliated with Korean academic institutions, Korean finance scholars who are currently affiliated with international and nonacademic institutions also make considerable contributions to the finance literature. Panel B of Table 3 lists 20 leading Korean researchers currently affiliated with international institutions. A large proportion of these researchers (12 out of 20) had prior Korean institution experience. The 20 leading researchers contribute 151 
Table 3 Leading researchers (1990-2010)

This table shows the top-20 authors in Korean academic institutions and in international and non-academic institutions. The ranking metric is the wt-articles in a set of 24 finance journals. We also present the AAI-articles and total appearance. Many local Korean authors have international experience before they settle in Korea. Similarly, many international Korean authors have Korean experience during their careers. To be in Panel A, an author needs to be affiliated with a Korean academic institution as of 15 March 2011. ${ }^{a}$ Visiting experience; "pre-doctoral experience. " $t$ " indicates a tie. AAI, author-affiliation index.

Panel A: Among Korean academic institution (author has most recently affiliated with a Korean academic institution)

\begin{tabular}{|c|c|c|c|c|c|c|}
\hline Rank & Leading author & $\begin{array}{l}\text { Wt- } \\
\text { articles }\end{array}$ & $\begin{array}{l}\text { AAI- } \\
\text { articles }\end{array}$ & $\begin{array}{l}\text { Total } \\
\text { appearance }\end{array}$ & $\begin{array}{l}\text { Institution } \\
\text { (most recent) }\end{array}$ & $\begin{array}{l}\text { International } \\
\text { experience }\end{array}$ \\
\hline 1 & Kim, Dongcheol & 8.50 & 368.82 & 13 & Korea U & Rutgers U \\
\hline 2 & Kim, In Joon & 6.25 & 170.73 & 12 & Yonsei U (Seoul) & New York U \\
\hline 3 & Lee, Jae Ha & 5.50 & 228.35 & 11 & SungKyunKwan U & U Oklahoma \\
\hline 4 & Lee, Sang Bin & 5.33 & 80.07 & 11 & Hanyang U (Seoul) & - \\
\hline 5 & Choe, Hyuk & 4.67 & 150.97 & 11 & Seoul National U & Penn State U \\
\hline 6 & Lee, Inmoo & 4.58 & 256.98 & 11 & $\begin{array}{l}\text { Korea Advanced } \\
\text { Institute Science } \\
\text { Tech }\end{array}$ & $\begin{array}{l}\text { Natl. U } \\
\text { Singapore }\end{array}$ \\
\hline 7 & Park, Jinwoo & 4.00 & 123.30 & 5 & $\begin{array}{l}\text { Hankuk U } \\
\text { Foreign Studies }\end{array}$ & Kansas State U \\
\hline 8 & Shin, Hyun-Han & 3.83 & 122.47 & 9 & Yonsei U (Seoul) & SUNY-Buffalo \\
\hline $9 t$ & Ahn, Hee-Joon & 3.33 & 103.97 & 10 & SungKyunKwan U & $\begin{array}{l}\text { City U } \\
\text { Hong Kong }\end{array}$ \\
\hline $9 t$ & Ahn, Dong-Hyun & 3.33 & 227.13 & 8 & Seoul National U & $\begin{array}{l}\text { U North } \\
\text { Carolina }\end{array}$ \\
\hline $9 t$ & Kim, Chang-Soo & 3.33 & 104.87 & 7 & Yonsei U (Seoul) & St John's U \\
\hline 12 & Hwang, Soosung & 3.25 & 59.77 & 8 & SungKyunKwan U & Cass Bus. School \\
\hline 13 & Gerlach, Jeffrey R & 3.00 & 75.00 & 3 & SungKyunKwan U & $\begin{array}{l}\text { College } \\
\text { William } \\
\text { and Mary }\end{array}$ \\
\hline 14 & Kho, Bong-Chan & 2.92 & 143.88 & 6 & Seoul National U & - \\
\hline 15 & Kim, Soyoung & 2.50 & 41.00 & 4 & Seoul National U & U Illinois \\
\hline $16 \mathrm{t}$ & Chay, J B & 2.33 & 109.07 & 5 & SungKyunKwan U & Auckland U \\
\hline $16 t$ & Cho, Jin-Wan & 2.33 & 99.98 & 4 & Korea U & $\begin{array}{l}\text { Carnegie } \\
\text { Mellon U }\end{array}$ \\
\hline 18 & Kim, Sol & 2.25 & 33.28 & 4 & $\begin{array}{l}\text { Hankuk U } \\
\text { Foreign Studies }\end{array}$ & - \\
\hline $19 t$ & Lee, Dong Wook & 2.17 & 61.55 & 4 & Korea U & U Kentucky \\
\hline $19 t$ & Moon, Doocheol & 2.17 & 31.27 & 5 & $\begin{array}{l}\text { Yonsei U } \\
\text { (Seoul) }\end{array}$ & $\begin{array}{l}\text { SUNY-Old } \\
\text { Westbury }\end{array}$ \\
\hline \multirow[t]{2}{*}{$19 t$} & Park, Young S & 2.17 & 52.85 & 5 & Sogang U & $\begin{array}{l}\text { International } \\
\text { U Japan }\end{array}$ \\
\hline & $\begin{array}{c}\text { Total (full } \\
\text { sample) }\end{array}$ & 77.74 & 2645.312645 .31 & 156 & & \\
\hline
\end{tabular}


Table 3 (Continued)

\begin{tabular}{|c|c|c|c|c|c|c|}
\hline Rank & Leading author & $\begin{array}{l}\text { Wt- } \\
\text { articles }\end{array}$ & $\begin{array}{l}\text { AAI- } \\
\text { articles }\end{array}$ & $\begin{array}{l}\text { Total } \\
\text { appearance }\end{array}$ & Institution & $\begin{array}{l}\text { Korean institution } \\
\text { experience }\end{array}$ \\
\hline 1 & Chung, Kee H & 23.92 & 681.78 & 49 & SUNY-Buffalo & Yonsei $\mathrm{U}^{\mathrm{a}}$ \\
\hline 2 & Lee, Bong-Soo & 20.33 & 764.95 & 34 & Florida State U & $\begin{array}{l}\text { Korea Advanced } \\
\text { Institute } \\
\text { Science Tech }\end{array}$ \\
\hline 3 & Kang, Jun-Koo & 11.00 & 701.09 & 26 & Nanyang Tech U & Korea U \\
\hline 4 & Bae, Kee-Hong & 7.50 & 295.80 & 18 & York U & Korea U \\
\hline $5 t$ & Rhee, S Ghon & 7.00 & 212.83 & 19 & U Hawaii-Manoa & SungKyunKwan U \\
\hline $5 t$ & Choi, E Kwan & 7.00 & 102.90 & 8 & Iowa State U & - \\
\hline 7 & Bae, Sung C & 6.50 & 148.35 & 14 & $\begin{array}{l}\text { Bowling Green } \\
\text { State U }\end{array}$ & Korea $\mathrm{U}^{\mathrm{a}}$ \\
\hline $8 \mathrm{t}$ & Kim, Kenneth A & 6.25 & 207.92 & 15 & SUNY-Buffalo & Yonsei U (Seoul) $)^{\mathrm{a}}$ \\
\hline $8 \mathrm{t}$ & Lee, Insup & 6.25 & 90.42 & 11 & $\begin{array}{l}\text { Haymarket } \\
\text { Media Group }\end{array}$ & - \\
\hline 10 & Chang, Saeyoung & 5.67 & 214.58 & 10 & $\begin{array}{l}\text { U Nevada Las } \\
\text { Vegas }\end{array}$ & - \\
\hline 11 & Park, Sangkyun & 5.50 & 181.65 & 6 & $\begin{array}{c}\text { Office Magt. and } \\
\text { Budget (USA) }\end{array}$ & - \\
\hline $12 t$ & Chung, Y Peter & 5.33 & 279.28 & 12 & $\begin{array}{l}\text { U California- } \\
\text { Riverside }\end{array}$ & Daewoo $^{\mathrm{b}}$ \\
\hline $12 \mathrm{t}$ & Jo, Hoje & 5.33 & 134.67 & 13 & Santa Clara U & Seoul National $\mathrm{U}^{\mathrm{a}}$ \\
\hline $12 t$ & Eun, Cheol S & 5.33 & 194.75 & 12 & Georgia Tech & Bank of Korea ${ }^{b}$ \\
\hline 15 & Song, Moon H & 5.17 & 181.77 & 11 & San Diego State U & - \\
\hline 16 & Choi, Jongmoo Jay & 5.00 & 129.37 & 12 & Temple U & Yonsei $\mathrm{U}^{\mathrm{a}}$ \\
\hline 17 & Lee, Jason & 4.67 & 115.68 & 11 & U Alberta & - \\
\hline 18 & Kim, Yong $\mathrm{H}$ & 4.58 & 256.98 & 11 & U Cincinnati & Seoul National $\mathrm{U}^{\mathrm{a}}$ \\
\hline 19 & Kim, Suk-Joong & 4.50 & 117.45 & 12 & U Sydney & - \\
\hline \multirow[t]{2}{*}{20} & Choi, Yoon K & 4.17 & 59.98 & 8 & U Central Florida & - \\
\hline & Total & 151.00 & 5072.19 & 312 & & \\
\hline
\end{tabular}

Panel C: A comparison of the finance research productivity in sub-periods among the leading local Korean and international Korean scholars

\begin{tabular}{|c|c|c|c|c|c|c|c|c|}
\hline & \multirow[b]{2}{*}{ Period } & \multirow[b]{2}{*}{$N$} & \multicolumn{2}{|c|}{ Wt-articles } & \multicolumn{2}{|c|}{ AAI-articles } & \multicolumn{2}{|c|}{$\begin{array}{l}\text { Total } \\
\text { appearances }\end{array}$} \\
\hline & & & Total & Average & Total & Average & Total & Average \\
\hline \multirow{3}{*}{$\begin{array}{l}\text { Local Korean } \\
\text { scholars }\end{array}$} & 1990-2010 & 21 & 0 & 3.69 & 00 & 125.97 & 156 & 7.43 \\
\hline & 2001-2010 & 23 & 48.33 & 2.10 & 1486.87 & 64.65 & 103 & 4.48 \\
\hline & 2006-2010 & 20 & 31.17 & 1.56 & 956.28 & 47.81 & 68 & 3.40 \\
\hline \multirow{3}{*}{$\begin{array}{l}\text { International } \\
\text { Korean scholars }\end{array}$} & 1990-2010 & 20 & 151.00 & 7.55 & 5072.19 & 253.61 & 312 & 15.60 \\
\hline & 2001-2010 & 21 & 85.67 & 4.08 & 2881.08 & 137.19 & 193 & 9.19 \\
\hline & 2006-2010 & 22 & 51.42 & 2.34 & 1708.77 & 77.67 & 113 & 5.14 \\
\hline
\end{tabular}


wt-articles and 5072.19 AAI-articles, and make 312 total appearances. Among them, Kee H. Chung (SUNY-Buffalo), Bong-Soo Lee (Florida State University), and Jun-Koo Kang (Nanyang Technological University) are the three leaders of the group. In Panel $\mathrm{C}$ of Table 3, we present a comparison of average productivity among the top-20 scholars to examine the research productivity gap between Korean scholars outside and Korean scholars inside Korea. The results in Panel C clearly show that the gap is shrinking in the more recent time period. For instance, during 1990-2010, overseas leading Korean scholars contribute an average 7.55 wt-articles, whereas the average contribution by local Korean scholars is only 3.69 wt-articles. That is, overseas scholars' research output equates to approximately 205\% (7.55 wt-articles/3.69 wt-articles) of the local scholars' output. During 20012010, this ratio drops slightly to $194 \%$ (4.08 wt-articles/2.10 wt-articles), dropping further to $150 \%$ (2.34 wt-articles/1.56 wt-articles) in the most recent 5 years. AAIarticles and total appearances reveal similar reductions in the gap between local and oversea Korean scholars.

We reproduce Table 3 with only seven premier finance journals for the full sample. The results are in Appendix 3. The leading authors in Appendix 3 are qualitatively the same as in Table 3 , with minor differences in the relative ranking.

\subsection{Comparative Productivity}

We conduct a benchmarking analysis to compare the productivity of Korean authors with authors in other Asia-Pacific countries; that is, Australia, China, Hong Kong, Japan, New Zealand, Singapore, and Taiwan. ${ }^{8}$ To draw a meaningful comparison, we use the same data, sample period, and metrics to calculate the finance research productivity in these Asia-Pacific countries. To calculate productivity per faculty, we conducted Internet research on 20 May 2011 to determine the faculty size of the academic institutions in the Asia-Pacific countries, including Korea. ${ }^{9}$ Specifically, we include only tenure and tenure-track professors.

Table 4 presents a comparison of research productivity between Korean authors and authors in other Asia-Pacific countries. Panel A includes all authors that appear in the sample $(N)$ in the specific country and shows research productivity per author by each country; and Panel B presents the research productivity per faculty member of the top-5 academic institutions of each country. From the results presented in Panel A, we notice that Korean authors affiliated with Korean academic institutions produced, on average, 1.03 wt-articles per author during 1990-2010.

\footnotetext{
${ }^{8}$ Several of the Korean international authors are affiliated with institutions in the Asia-Pacific countries.

${ }^{9}$ Chan et al. (2011b) suggest that it is impossible to accurately determine the exact faculty size each year for the sample due to the fact that a finance department size might change over time. Hence, we need to exercise care to interpret the productivity per faculty statistics.
} 


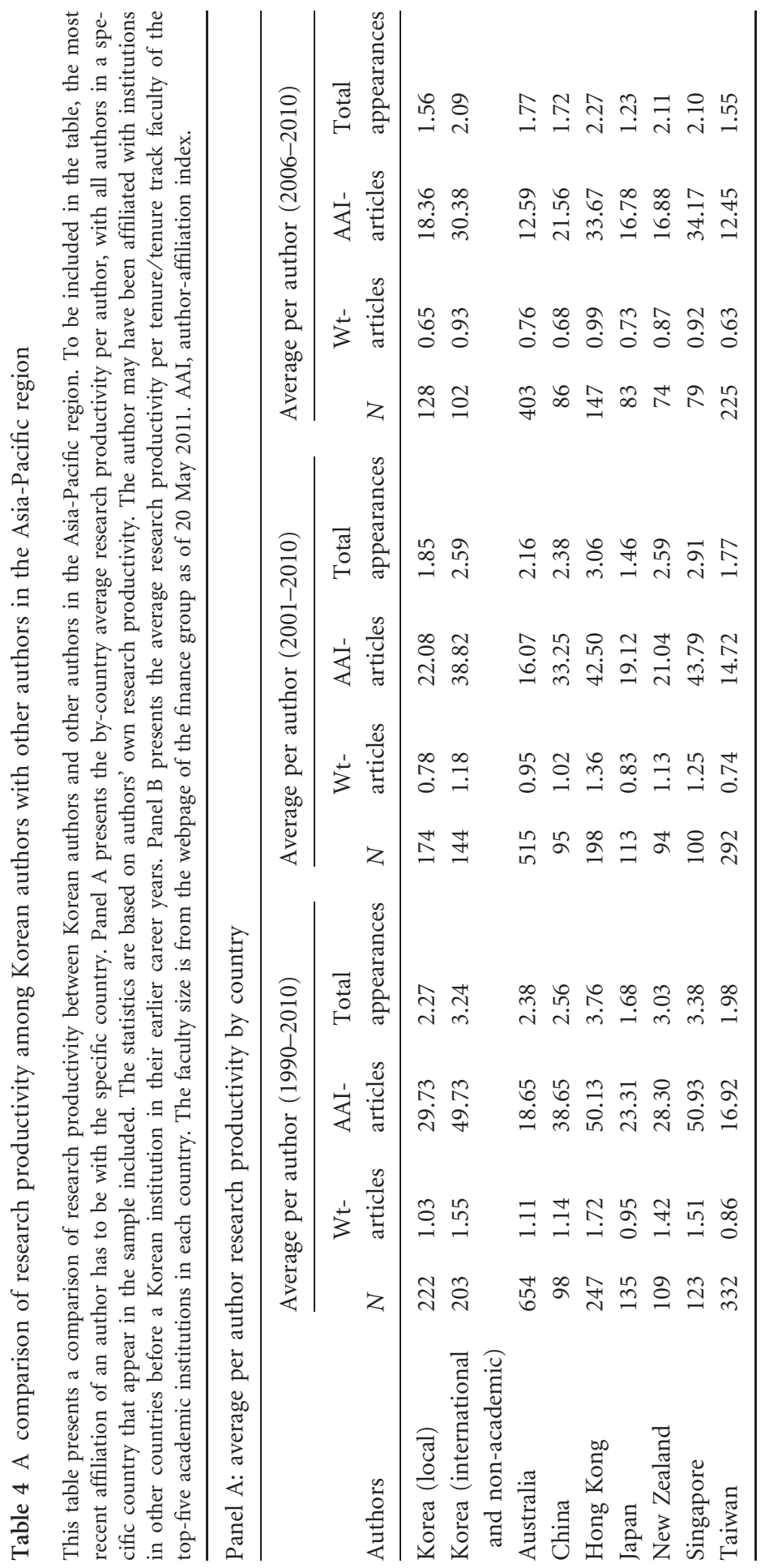




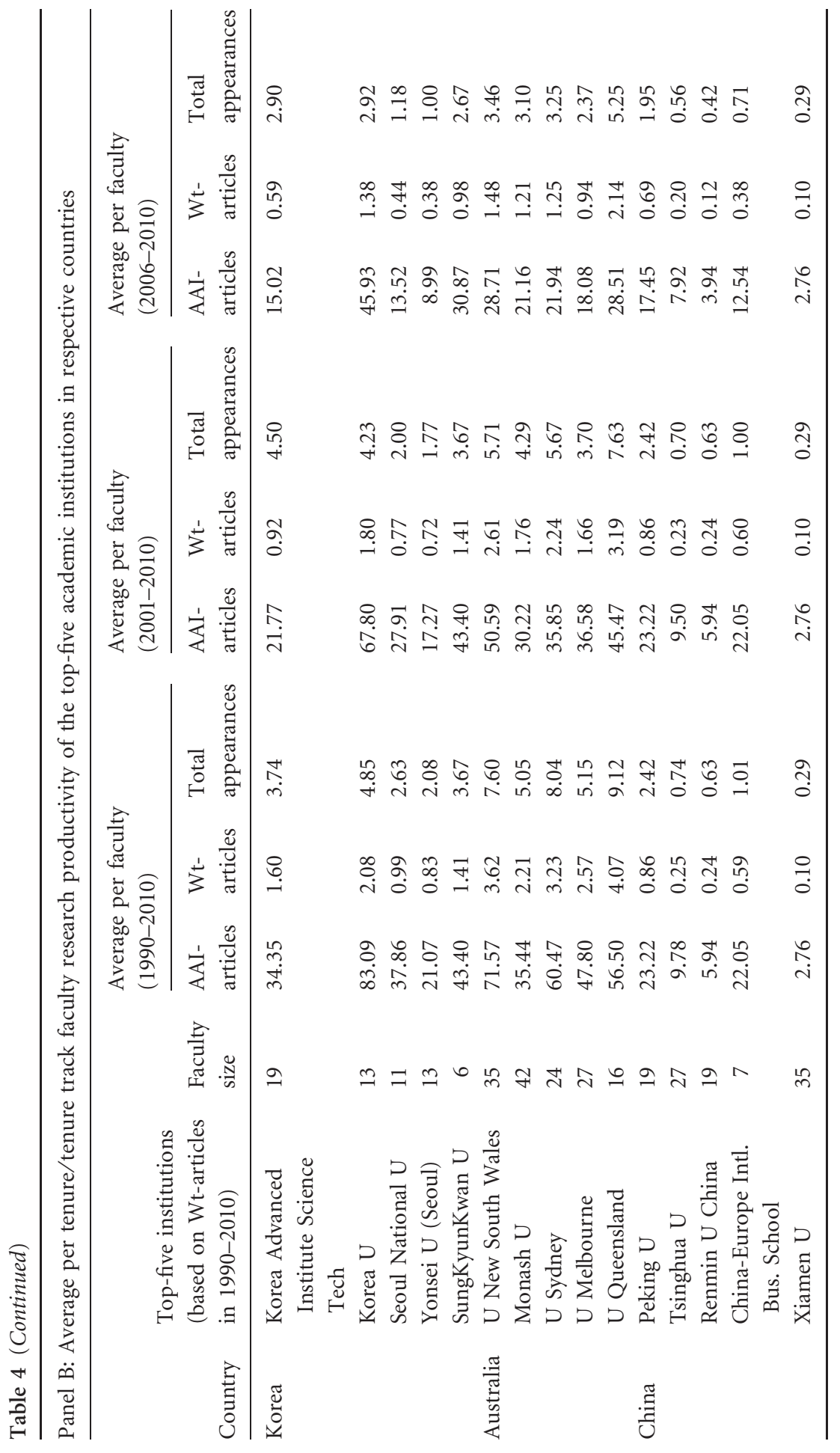


A Retrospective Analysis of Financial Research Among Korean Institutions and Authors

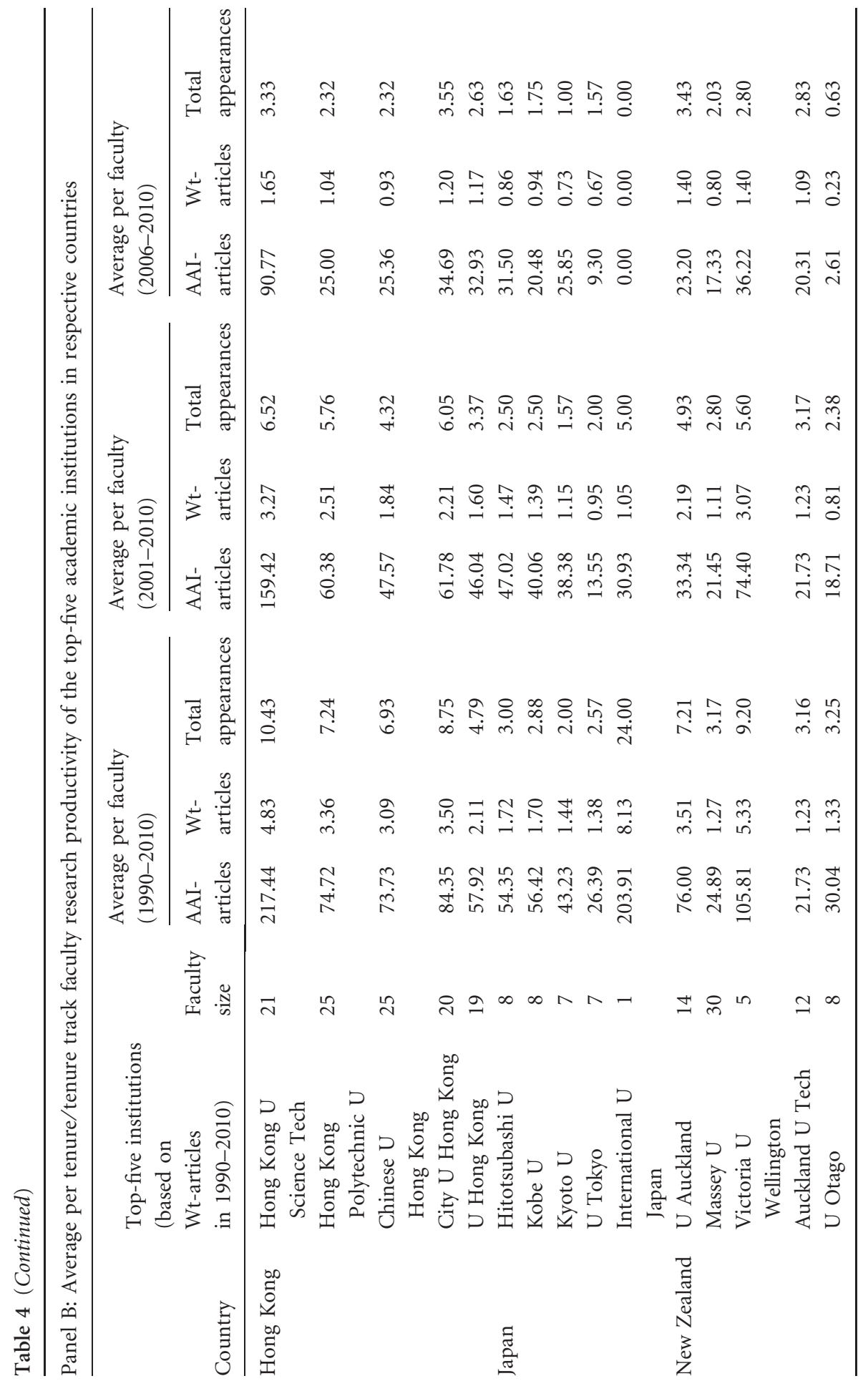




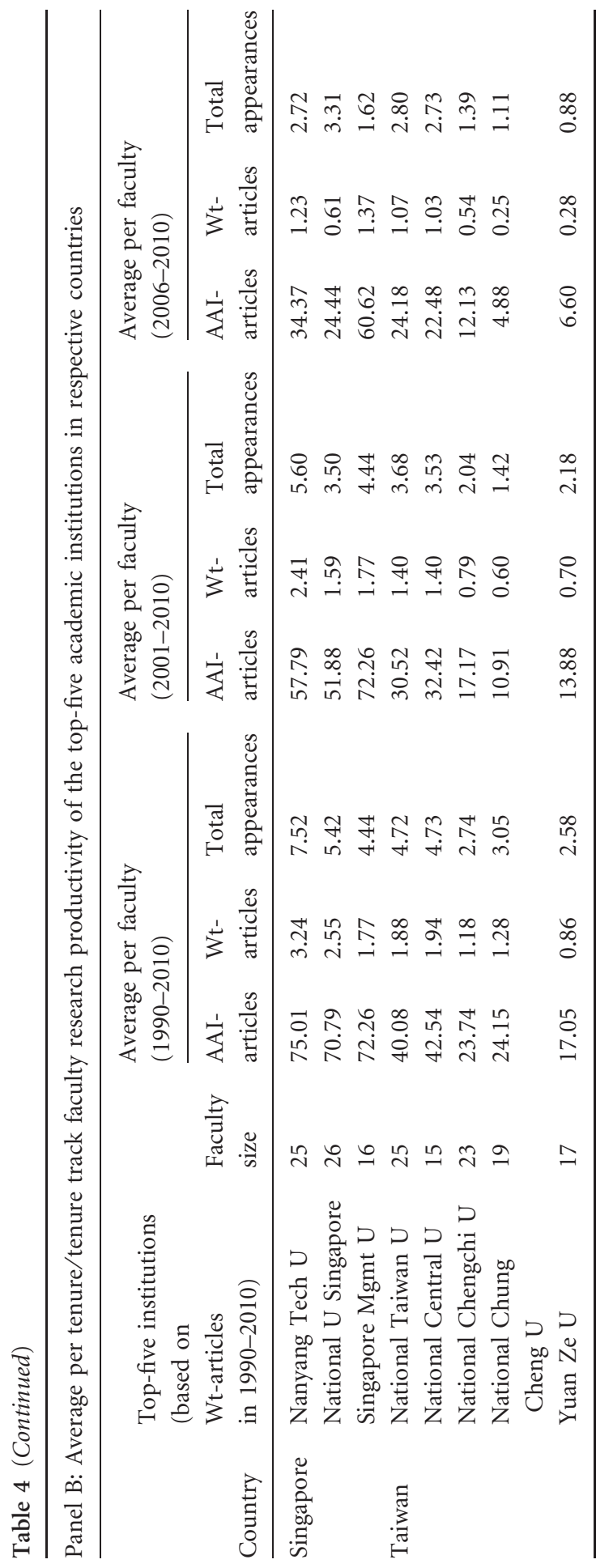


Local Korean authors are, on average, more productive than authors in Japan and Taiwan, but less productive than authors in Australia, China, Hong Kong, New Zealand, and Singapore. ${ }^{10}$ The international and non-academic Korean authors, however, produced $1.5 \mathrm{wt}$-articles per author during 1990-2010, which is more than the rest of the countries, with the exception of Hong Kong. If we examine the same statistics during 2001-2010 and 2006-2010, Japanese authors surpass Korea authors in terms of average wt-articles.

Panel B in Table 4 presents the research productivity per tenure/tenure track faculty during 2006-2010, 2001-2010, and 1990-2010. During 1990-2010, Korea University and the Advanced Institute of Science and Technology produced 2.08 and 1.60 wt-articles per faculty, figures comparable to other top-rated universities in Asia-Pacific countries. Examining the most recent 5 years (2006-2010), the leading Korean universities, such as Korea University and SungKyunKwan University, are very close to the leading universities in Australia and Hong Kong and do better than many universities in China, Japan, Singapore, and Taiwan in terms of average wt-articles. In summary, we can conclude that Korean authors are comparable to authors in other Asia-Pacific countries and leading Korean universities are comparable to their counterpart in other Asia-Pacific countries in terms of publishing articles in international finance journals.

\section{Summary}

Using the publication records of 24 leading finance journals during 1990-2010, we provide a retrospective analysis of the research performance by Korean institutions and scholars. Overall, Korean universities performed well, publishing 158.50 wtarticles over 1990-2010. The number of wt-articles published increased steadily over the study period.

Noteworthy is that Korean universities, in general and especially the most recent five years, have had a considerable increase in the number of studies appearing in international finance journals. A large proportion of financial research is contributed by a selected group of faculty affiliated with higher-ranked Korean universities.

Compared to their Korean peers affiliated with international institutions, Korean authors affiliated with Korean institutions are less productive in terms of publishing in the international finance journals, but the gap has been shrinking the most recent five years. With few exceptions, the Korean authors who publish successfully in international journals have had prior international experience, through affiliations with international institutions during their studies or academic career. This evidence highlights the need for Korean scholars to expand their international exposure and experience. The international experience augments their exposure to diverse research

\footnotetext{
${ }^{10}$ The high average per faculty in China might be due to its small number of authors in the sample.
} 
topics and methods, and facilitates collaboration with international scholars, which can positively contribute to success in international journal publications.

In conclusion, this study offers an assessment of financial research productivity that can be used to gauge the financial research performance of Korean institutions and scholars. Various constituents might find this assessment useful in making or adjusting their promotion, tenure, merit, enrollment, employment, and resource allocation decisions. In general, Korean universities have been successful in producing financial research over the past two decades. Over the period, many have exhibited positive growth, with a few sizable upsurges in publishing in international financial journals.

\section{References}

Anderson, D. L., and J. Tressler, 2008, Research output in New Zealand economics departments 2000-2006, Working Paper, University of Waikato, Hamilton, New Zealand.

Ashton, D., V. Beattie, J. Broadbent, C. Brooks, P. Draper, M. Ezzamel et al., 2009, British research in accounting and finance (2001-2007): The 2008 research assessment exercise, British Accounting Review 41, pp. 199-207.

Booth, L., and F. Heath, 1990, Finance research at Canadian management and administration faculties, Canadian Journal of Administrative Science 7, pp. 43-50.

Carmona, S., I. Gutiérrez, and M. Cámara, 1999, A profile of European accounting research: Evidence from leading accounting journals, European Accounting Review 8, pp. 463-480.

Chan, K. C., C. R. Chen, and T. L. Steiner, 2001, Research productivity of the finance profession in the Asia-Pacific region, Pacific-Basin Finance Journal 9, pp. 265-280.

Chan, K. C., C. R. Chen, and T. L. Steiner, 2003, Production in the finance literature, institutional reputation, and labor mobility in the academia: A global perspective, Financial Management 31, pp. 131-156.

Chan, K. C., C. Chen, and T. L. Steiner, 2004, Research productivity of the finance profession in Europe, Journal of Business Finance and Accounting 31, pp. 177-213.

Chan, K. C., C. Chen, and P. Lung, 2005, A ranking of finance programs in the Asia-Pacific region: An update, Pacific-Basin Finance Journal 13, pp. 489-602.

Chan, K. C., C. R. Chen, and L. T. W. Cheng, 2006, A ranking of accounting research output in the European region, Accounting and Business Research 36, pp. 3-17.

Chan, K. C., C. R. Chen, and P. Lung, 2007, One-and-a-half decades of global research output in finance: 1990-2004, Review of Quantitative Finance and Accounting 28, pp. 417-439.

Chan, K. C., C. H. Chang, and C. R. Chen, 2011a, Financial research in the European region: A long-term assessment (1990-2008), European Financial Management 17, pp. 391-411.

Chan, K. C., C. R. Chen, and T. Lee, 2011b, A long-term assessment of finance research performance among Asia-Pacific academic institutions (1990-2008), Pacific-Basin Finance Journal 19, pp. 157-171.

Chan, K. C., C. H. Chang, and Y. Chen, 2011c, Financial research in Canada: A long-run assessment of journal publications, Canadian Journal of Administrative Sciences 28, pp. 91-103. 
Chen, C. R., and Y. Huang, 2007, Author Affiliation Index, finance journal ranking, and the pattern of authorship, Journal of Corporate Finance 13, pp. 1008-1026.

Davies, J. B., M. G. Kocher, and M. Sutter, 2008, Economics research in Canada: A long-run assessment of journal publications, Canadian Journal of Economics 41, pp. 22-45.

Heck, J. L., and P. L. Cooley, 2009, Most prolific authors in the finance literature: 19592008, Working Paper. Available at SSRN: http://ssrn.com/abstract $=1355675$.

Hu, Q., and T. G. Gill, 2000, IS faculty research productivity: Influential factors and implications, Information Resources Management Journal 13, pp. 15-25.

Jarnecic, E., R. Segara, L. Segara, and J. P. Westerholm, 2008, The scholarly output of universities and academics in the European region who publish in major finance journals: 2000-2007, Australasian Accounting Business and Finance Journal 2, pp. 26-56.

Kalaitzidakis, P., T. P. Mamuneas, and T. Stengos, 1999, European economics: An analysis based on publications in the core journals, European Economic Review 43(1), pp. 1501168.

Kim, S., and J. H. Lee, 2006, Changing facets of Korean higher education: Market competition and the role of the state, Higher Education 52, pp. 557-587.

Lucas, R. F., 1995, Contributions to economics journals by Canadian economics profession, 1981-90, Canadian Journal of Economics 28, pp. 945-960.

Moon, M., and K. S. Kim, 2001, A case of Korean higher education reform: The Brain Korea 21 project, Asian Pacific Education Review 2, pp. 96-105.

Pomfret, R., and L. C. Wang, 2003, Evaluating the research output of Australian universities' economics departments, Australian Economic Papers 42, pp. 418-441.

Rugman, A. M., 2008, Thirty years of international business scholarship in Canada, Canadian Journal of Administrative Sciences 25, pp. 271-278.

Serenko, A., M. Cocosila, and O. Turel, 2008, The state and evolution of information systems research in Canada: A scientometric analysis, Canadian Journal of Administrative Sciences 25, pp. 279-294.

\section{Appendices}

Appendix 1 Author-affiliation index (AAI)

This appendix presents the author-affiliation index (AAI) for the 24 finance journals. The AAI is from Chen and Huang (2007). 'Accounting and Finance does not have an AAI value. We assign it an AAI value of 0.094 , the lowest value among all journals.

\begin{tabular}{|c|c|c|}
\hline Journal (full name) & Abbreviated name & AAI value $\times 100$ \\
\hline Accounting and Finance ${ }^{\mathrm{a}}$ & $A F$ & 9.4 \\
\hline European Financial Management & $E F M$ & 19.9 \\
\hline Financial Analysts Journal & $F A J$ & 37.2 \\
\hline Financial Management & $F M$ & 37.0 \\
\hline The Financial Review & $F R$ & 20.6 \\
\hline International Review of Economics and Finance & IREF & 14.7 \\
\hline Journal of Business & $J B$ & 58.8 \\
\hline Journal of Banking and Finance & $J B F$ & 19.7 \\
\hline Journal of Business Finance and Accounting & $J B F A$ & 9.4 \\
\hline
\end{tabular}


Appendix 1 (Continued)

\begin{tabular}{lll}
\hline Journal (full name) & Abbreviated name & AAI value $\times 100$ \\
\hline Journal of Corporate Finance & JCF & 51.1 \\
Journal of Empirical Finance & $J E m F$ & 23.9 \\
Journal of Finance & $J F$ & 80.3 \\
Journal of Financial Economics & JFE & 70.9 \\
Journal of Financial Intermediation & JFI & 35.3 \\
Journal of Futures Markets & JFM & 15.0 \\
Journal of Financial Markets & JFMkt & 48.4 \\
Journal of Financial and Quantitative Analysis & JFQA & 59.9 \\
Journal of Financial Research & JFR & 27.2 \\
Journal of Financial Services Research & JFSR & 24.7 \\
Journal of International Money and Finance & JIMF & 14.2 \\
Journal of Portfolio Management & $J P M$ & 15.8 \\
Pacific-Basin Finance Journal & PBFJ & 11.4 \\
Review of Financial Studies & RFS & 80.3 \\
Review of Quantitative Finance and Accounting & RQFA & 20.3 \\
\hline
\end{tabular}

Appendix 2 Financial research productivity among Korean academic institutions in seven premier finance journals (1990-2010)

This appendix presents the ranking of Korean institutions based on weighted number of articles (wt-articles) in seven leading finance journals. The seven journals are: Journal of Finance, Journal of Financial Economics, Review of Financial Studies, Journal of Financial and Quantitative Analysis, Journal of Business, Financial Management, and Journal of Banking and Finance. AAI, author-affiliation index.

\begin{tabular}{|c|c|c|c|c|}
\hline Rank & Institution & Wt-articles & AAI-articles & Total appearance \\
\hline 1 & Korea U & 11.88 & 705.12 & 31 \\
\hline 2 & Seoul National U & 5.00 & 300.90 & 14 \\
\hline 3 & Korea Advanced Institute Science Tech & 3.70 & 183.93 & 10 \\
\hline 4 & SungKyunKwan U & 3.67 & 162.23 & 11 \\
\hline 5 & Hanyang U (Seoul) & 2.36 & 140.41 & 7 \\
\hline 6 & Sogang U & 2.17 & 71.03 & 6 \\
\hline 7 & Yonsei U (Seoul) & 2.08 & 127.75 & 6 \\
\hline 8 & Hankuk U Foreign Studies & 1.67 & 110.30 & 3 \\
\hline 9 & Ewha Women's U & 1.58 & 87.09 & 4 \\
\hline 10 & $\begin{array}{l}\text { KDI School of Public Policy and } \\
\text { Management }\end{array}$ & 1.50 & 29.55 & 2 \\
\hline 11 & Seoul City U & 1.25 & 75.83 & 2 \\
\hline 12 & Kyung Hee U & 1.00 & 53.95 & 2 \\
\hline 13 & Pohang U Science Tech & 0.83 & 6.57 & 2 \\
\hline 14 & Chung-Ang $U$ & 0.67 & 53.53 & 2 \\
\hline 15 & Chungbuk National U & 0.50 & 18.50 & 1 \\
\hline 16 & Kyungpook National U & 0.50 & 29.40 & 1 \\
\hline
\end{tabular}


Appendix 2 (Continued)

\begin{tabular}{lllcl}
\hline Rank & Institution & Wt-articles & AAI-articles & Total appearance \\
\hline 17 (tied) & Changwon National U & 0.33 & 19.97 & 1 \\
17 (tied) & Chonbuk National U & 0.33 & 6.57 & 1 \\
17 (tied) & Chungnam National U & 0.33 & 12.33 & 1 \\
17 (tied) & Dongeui U (Korea) & 0.33 & 12.33 & 1 \\
17 (tied) & Sookmyung Women's U & 0.33 & 26.77 & 1 \\
17 (tied) & Sungshin Women's U & 0.33 & 6.57 & 1 \\
17 (tied) & U Seoul & 0.33 & 6.57 & 1 \\
24 (tied) & Ajou U & 0.25 & 20.08 & 1 \\
24 (tied) & Hongik U & 0.25 & 4.93 & 1 \\
26 & Kongju National U & 0.20 & 3.94 & 1 \\
\hline
\end{tabular}

Appendix 3 Leading researchers in seven premier finance journals (1990-2010)

This appendix presents the top-20 authors in Korean academic institutions and in international and non-academic institutions using only seven premier finance journals. The ranking metric is the wtarticles. We also present the author-affiliation index (AAI) articles and total appearance. To be in Panel A, an author needs to be affiliated with a Korean academic institution as of March 15, 2011.

Panel A: Among Korean academic institution (author has most recently affiliated with a Korean academic institution)

\begin{tabular}{clllll}
\hline Rank & Leading author & Wt-articles & AAI-articles & $\begin{array}{l}\text { Total } \\
\text { appearance }\end{array}$ & $\begin{array}{l}\text { Institution } \\
\text { (most recent) }\end{array}$ \\
\hline 1 & Kim, Dongcheol & 4.67 & 290.65 & 7 & Korea U \\
2 & Lee, Inmoo & 3.08 & 206.16 & 7 & $\begin{array}{c}\text { Korea Advanced } \\
\text { Institute Science Tech }\end{array}$ \\
& & & & & Seoul National U \\
3 & Ahn, Dong-Hyun & 3.00 & 220.50 & 7 & SungKyunKwan U \\
4 & Lee, Jae Ha & 2.50 & 169.60 & 5 & Seoul National U \\
5 & Kho, Bong-Chan & 1.92 & 126.23 & 4 & SungKyunKwan U \\
6 & Hwang, Soosung & 1.67 & 32.83 & 4 & Hankuk U Foreign \\
7 & Park, Jinwoo & 1.50 & 89.85 & 2 & Studies \\
& & & & & Seoul National U \\
$8 \mathrm{t}$ & Choe, Hyuk & 1.33 & 83.73 & 4 & SungKyunKwan U \\
$8 \mathrm{t}$ & Chay, J B & 1.33 & 97.67 & 3 & Yonsei U (Seoul) \\
$8 \mathrm{t}$ & Kim, In Joon & 1.33 & 92.63 & 2 & Seoul National U \\
$8 \mathrm{t}$ & Chae, Joon & 1.33 & 86.87 & 2 & Sogang U \\
12 & Ahn, Seoungpil & 1.17 & 65.65 & 3 & Seoul National U \\
$13 \mathrm{t}$ & Hwang, Lee-Seok & 1.00 & 62.83 & 3 & Yonsei U (Seoul) \\
$13 \mathrm{t}$ & Kim, Chang-Soo & 1.00 & 44.63 & 3 & KDI School Public \\
$13 \mathrm{t}$ & Lee, Jinsoo & 1.00 & 29.75 & 3 & Policy \& Mgmt \\
& & & & & Korea U \\
$13 \mathrm{t}$ & Kim, Woojin & 1.00 & 75.60 & 2 & Yonsei U (Seoul) \\
$13 \mathrm{t}$ & Hahn, Jaehoon & 1.00 & 70.10 & 2 & \\
\hline & & & & &
\end{tabular}


Appendix 3 (Continued)

Panel A: Among Korean academic institution (author has most recently affiliated with a Korean academic institution)

\begin{tabular}{llcccl}
\hline Rank & Leading author & Wt-articles & AAI-articles & $\begin{array}{l}\text { Total } \\
\text { appearance }\end{array}$ & $\begin{array}{l}\text { Institution } \\
\text { (most recent) }\end{array}$ \\
\hline $13 \mathrm{t}$ & Lee, Hangyong & 1.00 & 70.10 & 2 & Hanyang U (Seoul) \\
$13 \mathrm{t}$ & Kim, Soyoung & 1.00 & 19.70 & 2 & Seoul National U \\
$13 \mathrm{t}$ & Park, Young S & 1.00 & 19.70 & 2 & Sogang U \\
$13 \mathrm{t}$ & Hong, Gwangheon & 1.00 & 19.70 & 2 & Sogang U \\
$13 \mathrm{t}$ & Cho, Myeong-Hyeon & 1.00 & 70.90 & 1 & Korea U \\
$13 \mathrm{t}$ & Joh, Sung Wook & 1.00 & 70.90 & 1 & Seoul National U \\
$13 \mathrm{t}$ & Sohn, Wook & 1.00 & 19.70 & 1 & KDI School Public \\
& & & & & Policy \& Mgmt \\
& Total & 36.83 & 2135.98 & 74 & \\
\hline
\end{tabular}

Panel B: Among international academic and non-academic institutions

\begin{tabular}{|c|c|c|c|c|c|}
\hline 1 & Lee, Bong-Soo & 12.17 & 601.13 & 19 & Florida State U \\
\hline 2 & Kang, Jun-Koo & 9.83 & 674.56 & 23 & Nanyang Tech U \\
\hline 3 & Chung, Kee H & 9.42 & 371.73 & 22 & SUNY-Buffalo \\
\hline 4 & Chung, Y Peter & 4.50 & 269.78 & 10 & U California-Riverside \\
\hline 5 & Park, Sangkyun & 3.50 & 109.15 & 4 & Federal Reserve Bank-NY \\
\hline 6 & Kim, E Han & 3.17 & 235.70 & 7 & U Michigan \\
\hline 7 & Rhee, S Ghon & 3.00 & 143.50 & 7 & U Hawaii \\
\hline $8 \mathrm{t}$ & Bae, Kee-Hong & 2.83 & 210.95 & 8 & York U \\
\hline $8 \mathrm{t}$ & Eun, Cheol S & 2.83 & 99.52 & 7 & Georgia Tech \\
\hline $8 \mathrm{t}$ & Choi, Jongmoo Jay & 2.83 & 91.27 & 7 & Temple U \\
\hline 11 & Chang, Saeyoung & 2.50 & 152.75 & 3 & U Hawaii \\
\hline 12 & Jo, Hoje & 2.33 & 127.73 & 5 & Santa Clara U \\
\hline $13 \mathrm{t}$ & Kim, Yongtae & 2.00 & 105.20 & 3 & Santa Clara U \\
\hline $13 \mathrm{t}$ & Byoun, Soku & 2.00 & 139.10 & 2 & Baylor U \\
\hline $13 \mathrm{t}$ & Park, Cheol & 2.00 & 139.10 & 2 & National U Singapore \\
\hline $13 \mathrm{t}$ & Choi, Yoon K & 2.00 & 95.80 & 2 & U Central Florida \\
\hline 17 & Song, Moon H & 1.83 & 110.67 & 4 & San Diego State U \\
\hline 18 & Kim, Chansog & 1.67 & 91.37 & 5 & City U Hong Kong \\
\hline $19 t$ & Lee, Jason & 1.50 & 79.95 & 3 & U Alberta \\
\hline $19 t$ & Kim, Youngsoo & 1.50 & 49.65 & 3 & U Regina \\
\hline $19 t$ & Kim, Oliver & 1.50 & 115.75 & 2 & UCLA \\
\hline $19 t$ & Lee, Moon Hoe & 1.50 & 77.15 & 2 & U Saskatchewan \\
\hline \multirow[t]{2}{*}{$19 t$} & Kim, Yong O & 1.50 & 69.75 & 2 & U Manitoba \\
\hline & Total & 77.91 & 4161.26 & 152 & \\
\hline
\end{tabular}

